\title{
Leczenie chirurgiczne chorych na raka piersi w Finlandii - czego możemy oraz czego powinniśmy nauczyć się z doświadczeń skandynawskich, czyli: podróże kształcą
}

O wyborze ośrodka uniwersyteckiego w Helsinkach jako miejsca odbycia stażu klinicznego zadecydowały dwie okoliczności. Pierwsza z nich to dane epidemiologiczne dotyczące zapadalności na raka piersi oraz osiągane wyniki leczenia tego nowotworu. Finlandia należy do krajów o najwyższym poziomie zachorowalności na nowotwory złośliwe piersi - około 90/100 000 nowych przypadków rocznie (dane z roku 2010 - vs około 50/100 000 w Polsce) [1]. Stanowi to ponad 32-procentowy udział tych zachorowań w ogólnej liczbie stwierdzanych nowotworów złośliwych (vs 22,4\% w Polsce) $[1,2]$. Jednocześnie w obu krajach umieralność chorych z powodu raka piersi jest bardzo zbliżona, wynosząc nieco ponad 14/100 000 [1]. Polskę i Finlandię różni także wartość wskaźnika przeżyć 5-letnich w raku piersi $(77,4$ vs 86,6, będący jednym z najwyższych w Europie) [1].

Drugim z powodów było nawiązanie przyjacielskich kontaktów podczas ostatniego Zjazdu Polskiego Towarzystwa Chirurgii Onkologicznej (Bydgoszcz 2014) z profesor Marjut Leidenius, zakończone zaproszeniem autorów tego sprawozdania do odwiedzenia prowadzonego przez panią profesor ośrodka chirurgii piersi. Jak dowiedzieliśmy się jeszcze przed wyjazdem, rocznie jest w nim leczonych operacyjnie ponad tysiąc chorych na raka piersi (zachorowania pierwszorazowe).

Dwutygodniowy pobyt w Breast Surgery Unit, Helsinki University Central Hospital, z całą pewnością pokazał, że uprawianie chirurgii w ośrodku zajmującym się leczeniem chorych na nowotwory nie musi i nie powinno kojarzyć się z pośpiechem (codzienna rzeczywistość - pytanie: „ile punktów zdążymy jeszcze „wyrobić”), presją czasu ("czy do godziny 15. zdołamy wykonać na jednej sali wszystkie z zaplanowanych pięciu zabiegów, a może tylko cztery") czy problemem niedogodności organizacyjnych. Pracując na co dzień w dobrych ośrodkach onkologicznych i w dobrych warunkach (lub nawet bardzo dobrych — także sprzętowych, choć zawsze mogłyby być lepsze), z dużą nostalgią przywołujemy w pamięci obrazy z pobytu na salach operacyjnych helsińskich szpitali.

W kraju takim jak Finlandia do przeszłości należą dyskusje o celowości lub dopuszczalności wykonania risk re- ducing mastektomii u chorych obciążonych mutacją genu BRCA1. Rozwiązano także problem refundacji kosztów związanych z przeprowadzeniem takiego zabiegu — jest on finansowany oczywiście przez narodowego płatnika w dziedzinie ochrony zdrowia (odpowiednik polskiego Narodowego Funduszu Zdrowia). Wydaje się, iż jedynym zagadnieniem do rozstrzygnięcia przez naszych gospodarzy w omawianym względzie był sposób rekonstrukcji amputowanych gruczołów piersiowych (uczestniczyliśmy w kilkugodzinnych jednoczasowych zabiegach odtworzenia obu piersi z użyciem uszypułowanych płatów skórno-mięśniowych opartych na mięśniach najszerszych grzbietu, płatów DIEP czy z wykorzystaniem endoprotez — zakończonych bardzo dobrym wczesnym efektem estetycznym).

W fińskim zespole chirurgicznym, który zajmuje się tylko leczeniem operacyjnym chorób piersi, tzw. breast surgeon, jest chirurg po odbytym szkoleniu w ośrodku referencyjnym i po zdobyciu odpowiednich umiejętności. Niezastąpione miejsce zajmuje specjalista chirurgii plastycznej. Może być on stałym członkiem tego zespołu, jak również operatorem dochodzącym z innego ośrodka w celu wykonania konkretnych zabiegów i procedur. Operacje redukcyjne, często stosowany lipotransfer korekcyjny piersi czy inne zabiegi mammoplastyczne w sposób znaczący uzupełniają bardzo szeroki wachlarz technik onkoplastycznych doświadczonego zespołu prof. Leidenius (ponad $80 \%$ operacji nowotworów piersi, w jakich uczestniczyliśmy czy które obserwowaliśmy, były wykonywane z zastosowaniem technik onkoplastycznych). Sprawą oczywistą jest wykorzystywanie izotopów: technetu do identyfikacji węzła wartowniczego (zaoszczędzenie węzłów chłonnych) i jodu (tzw. seed) do identyfikacji zmian niepalpacyjnych piersi.

Każda pacjentka leczona w Breast Surgery Unit jest omawiana na spotkaniu „piersiowego"zespołu wielodyscyplinarnego, zbierającego się dwa razy w tygodniu. W jego skład wchodzą chirurdzy, radiolodzy, patomorfolog, radioterapeuta i chemioterapeuta. Biorąc udział w tych zebraniach (specjalnie dla nas były prowadzone w języku angielskim), mieliśmy możliwość oglądania preparatów histopatologicznych, interpretacji badań radiologicznych (USG, MMG, MRI) 
czy wysłuchania proponowanej przez onkologów klinicznych procedury kwalifikacji chorych do dalszego leczenia uzupełniającego. W niezaprzeczalny sposób połączenie wiedzy, umiejętności chirurgicznych i najnowszej techniki przekłada się na uzyskiwany w klinice końcowy wynik leczenia operacyjnego chorych.

Inny niż w Polsce jest fiński poziom finansowania procedur chirurgicznych związanych z leczeniem chorych na raka piersi. Umożliwia to wykonanie (bez pośpiechu, ale i bez zbędnej zwłoki) w Szpitalu Uniwersyteckim w Helsinkach trzech (czasem tylko dwóch) zabiegów na każdej z trzech sal operacyjnych przeznaczonych dla potrzeb Breast Surgery Unit (w przedziale czasowym od godziny 8:30 do 14:30). Jak taka liczba zabiegów dziennie mogłaby się przełożyć na stopień realizacji zapisów umowy z NFZ w ośrodkach, w których pracujemy (jak również na poziom wynagrodzeń, zwłaszcza w przypadku chirurga zatrudnionego w oparciu o umowę cywilno-prawną)? Cóż, postawione pytanie powinno jednak pozostać pytaniem retorycznym. Prof. Leidenius zwykła mawiać, że „zadowolony chirurg to dobry chirurg” (czytaj: dobre warunki pracy, satysfakcjonująca pensja).

$Z$ dostępnych wyliczeń wynika, że średni ogólny koszt leczenia chorych na raka piersi w Polsce w roku 2007 wyniósł około 30000 złotych, będąc jednym z najniższych w Europie $[3,4]$. Koszt chirurgicznego leczenia oszczędzającego gruczoł piersiowy u chorych w podobnym stadium zaawansowania i podobnymi chorobami towarzyszącymi, obejmujący kilkudniowy pobyt w szpitalu, został skalkulowany w naszym kraju (dane z roku 2009) na kwotę 1143 euro. W przypadku Finlandii osiągnął wartość 6165 euro [5]. Większość zabiegów oszczędzających pierś i węzły chłonne w klinice Prof. Leidenius było wykonywanych w ramach chirurgii jednego dnia, na dobę w szpitalu pozostawały osoby starsze, samotne czy z towarzyszącymi obciążeniami internistycznymi.

Jak wskazuje nazwa, chirurg w Finlandii zajmuje się leczeniem chirurgicznym chorych i większość czasu jego pracy zajmuje to właśnie zajęcie. Mimo iż Finlandia nie należy do krajów o niskim dochodzie narodowym, nie stać tutaj nikogo na płacenie chirurgowi za wykonywanie przez niego innych czynności. Można więc zaryzykować, że właśnie z tego powodu kontakty z chorymi w trybie ambulatoryjnym ograniczono do obustronnie akceptowanego minimum. Chora na raka piersi (wykrytym najczęściej dzięki wydajnie działającemu ogólnokrajowemu programowi mammografii skriningowej) trafia do chirurga w pełni zdiagnozowana, z wynikiem badania histopatologicznego po biopsji wykonywanej przez radiologa oraz kompletem badań potrzebnych do operacji. Natomiast kontrole po przeprowadzonym zabiegu kończą się zwykle z chwilą wygojenia się rany operacyjnej — chora jest pod opieka onkologa klinicznego, a następnie lekarza rodzinnego. I mimo, zwłaszcza z polskiego punktu widzenia, wysokiego poziomu abstrakcji opisanej sytuacji wszyscy zainteresowani są zadowoleni.

\section{Dr n. med. Tomasz Nowikiewicz}

Oddział Kliniczny Nowotworów Piersi i Chirurgii Rekonstrukcyjnej Centrum Onkologii w Bydgoszczy

e-mail: tomasz.nowikiewicz@gmail.com

\section{Dr n. med. Andrzej Kurylcio}

Klinika Chirurgii Onkologicznej

Uniwersytet Medyczny w Lublinie

\section{Piśmiennictwo}

1. Didkowska J, Wojciechowska U. Nowotwory piersi w Polsce i Europie — populacyjny punkt widzenia. Nowotwory J Oncol 2013; 63: 111-118.

2. Wojciechowska U, Didkowska J. Nowotwory w Polsce w 2012 roku. Nowotwory J Oncol 2013; 63: 197-216.

3. Kozierkiewicz A, Topór-Maadry R, Śliwczyński i wsp. Skuteczność i koszty leczenia raka piersi w Polsce; podejście regionalne. Nowotwory J Oncol 2014; 64: 24-32.

4. Herman K, Śliwczyński A, Wysocki WM. Wyniki, metody i koszty leczenia raka piersi w Polsce (w latach 2005-2007). Nowotwory J Oncol 2014; 64: 33-39.

5. Scheller-Kreinsen D, Quentin W, Geissler A i wsp. Breast cancer surgery and diagnosis-related groups (DRGs): patient classification and hospital reimbursement in 11 European countries. Breast 2013; 22: 723-732. 